\title{
"The role of foreign direct investment and trade on carbon emissions in Turkey"
}

\begin{tabular}{|c|c|}
\hline AUTHORS & $\begin{array}{l}\text { Gizem Kaya } \\
\text { M. Özgür Kayalica (D https://orcid.org/0000-0001-9828-7385 } \\
\mathbb{R} \text { https://publons.com/researcher/1984150/m-ozgur-kayalica/ } \\
\text { Merve Kumaş } \\
\text { Burc Ulengin }\end{array}$ \\
\hline ARTICLE INFO & $\begin{array}{l}\text { Gizem Kaya, M. Özgür Kayalica, Merve Kumaş and Burc Ulengin (2017). The } \\
\text { role of foreign direct investment and trade on carbon emissions in Turkey . } \\
\text { Environmental Economics, 8(1), 8-17. doi:10.21511/ee.08(1).2017.01 }\end{array}$ \\
\hline DOI & http://dx.doi.org/10.21511/ee.08(1).2017.01 \\
\hline RELEASED ON & Friday, 07 April 2017 \\
\hline LICENSE & $\begin{array}{l}(c) \text { EY-No } \\
\text { This work is licensed under a Creative Commons Attribution-NonCommercial } 4.0 \\
\text { International License }\end{array}$ \\
\hline JOURNAL & "Environmental Economics" \\
\hline ISSN PRINT & $1998-6041$ \\
\hline ISSN ONLINE & $1998-605 X$ \\
\hline PUBLISHER & LLC "Consulting Publishing Company "Business Perspectives" \\
\hline FOUNDER & LLC "Consulting Publishing Company "Business Perspectives" \\
\hline
\end{tabular}

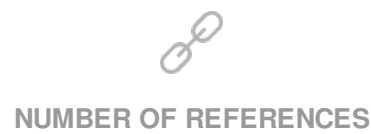

20

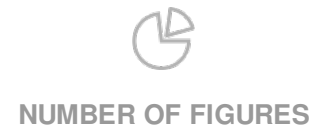

1
ニ:-

NUMBER OF TABLES

5

(C) The author(s) 2023. This publication is an open access article. 


\title{
Gizem Kaya (Turkey), M. Ozgur Kayalica (Turkey), Merve Kumas (Turkey), Burc Ulengin (Turkey) The role of foreign direct investment and trade on carbon emissions in Turkey
}

\begin{abstract}
This study aims to observe the long run and short run effects of gross domestic product, foreign direct investment inflows and trade on $\mathrm{CO}_{2}$ emissions and causality relationships between these factors, using annual data for the period of 1974-2010. The empirical results demonstrate that the inverted U-shaped relationship of environmental Kuznets curve is valid for Turkey. In addition, there are positive long run effects of foreign direct investment and trade openness on $\mathrm{CO}_{2}$ emissions. The authors also find a bidirectional causality relationship between $\mathrm{CO}_{2}$ emission and FDI.
\end{abstract}

Keywords: GDP, investment, trade, Environmental Kuznets curve, carbon emissions, Turkey. JEL Classification: Q53, Q56.

\section{Introduction}

The consequences of economic growth and income on environment have been widely discussed. One of the most common arguments in this concept is the environmental Kuznets curve (EKC) hypothesis that refers to the inverted U-shaped relationship between environmental indicators and income. This hypothesis asserts that after a certain period, the negative impact of economic development on environment reverses and economic growth compensates the deterioration caused by the early stages of economic development and improves environment (Stern, 1998). Although there are many studies testing the EKC hypothesis, they propound many different results mainly because of the sample range/region and environmental indicator used in their models. For example, the studies of Torras and Boys (1998) and Grossman and Krueger (1995) confirm the EKC hypothesis for sulfur dioxide $\left(\mathrm{SO}_{2}\right)$, but they suggest a monotonically decreasing relationship for heavy particles. Holtz-Eakin and Selden (1995) use the sample of 130 countries for the period 1951-1986. They find that carbon dioxide $\left(\mathrm{CO}_{2}\right)$ emissions initially increase with GDP and later decline. On the other hand, there are some studies that conflict with the EKC hypothesis for

(c) Gizem Kaya, M. Ozgur Kayalica, Merve Kumas, Burc Ulengin, 2017.

Gizem Kaya, Ph.D. Candidate in Econometrics, Department of Management Engineering, and TEDRC (Technology and Economic Development Research Centre), Istanbul Technical University, Istanbul, Turkey.

M. Ozgur Kayalica, Professor of Economics, Department of Management Engineering, and TEDRC (Technology and Economic Development Research Centre), Istanbul Technical University, Istanbul, Turkey.

Merve Kumas, MS.c in Economics, Department of Management Engineering, Istanbul Technical University, Istanbul, Turkey.

Burc Ulengin, Professor of Econometrics, Department of Management Engineering, Istanbul Technical University, Istanbul, Turkey.

This is an Open Access article, distributed under the terms of the Creative Commons Attribution-NonCommercial 4.0 International license, which permits re-use, distribution, and reproduction, provided the materials aren't used for commercial purposes and the original work is properly cited.
$\mathrm{CO}_{2}$ emission, such as Roberts and Grimes (1997), Dijkgraaf and Vollebergh (2005), Galeotti et al. (2006) and for sulfur emission, such as Perman and Stern (2003), Stern and Common (2001). Besides these, Bagliani et al. (2008) use ecological footprint (EF) as an environmental indicator and examine the relationship between EF and GDP. According to their results, EF has a monotonically increasing relationship with GDP.

The impacts of trade liberalization on environment have been mainly discussed through three effects: (i) scale effect; (ii) composition effect; (iii) technique effect. Scale effect refers to the increasing production in order to meet increasing demand in international markets. Composition effect explains the allocation of resources, which depends on the comparative advantage of countries. Finally, technique effect shows the impact of technology used in production activities, such as cleaner or environmentally friendly technology. The net impact of trade on environment is determined in relation to the weights of these three effects (Barrett, 2000). Frankel and Rose (2005) extend EKC analyzis by adding openness variable (the ratio of export and import to GDP) in to the model to see the effect of trade liberalization. The results of crosscountry analyzis confirm the EKC hypothesis and show positive impact of trade on air pollution. Similarly, Kacar and Kayalica (2014) use panel data analyzis for 42 countries over the period 1950-2000. They find an inverted U-shaped relationship between economic growth and sulfur emission in the presence of trade and population parameters. On the other hand, using the data of between 26 and 32 countries for the period 1975-1995, Cole and Elliot (2003) find that the technique effect can dominate the scale effect for $\mathrm{SO}_{2}$ and biochemical oxygen demand (BOD), but it is dominated by scale effect for nitrogen oxides $\left(\mathrm{NO}_{\mathrm{x}}\right)$ and $\mathrm{CO}_{2}$. Suri and Chapman (1998) use the sample of 31 countries for 20-year period (1971-1991) and they observe that 
when trade variables are added to the model, the turning point of the curve for energy consumption increases. Therefore, trade also has an impact to raise the turning point for pollutant emission caused by energy consumption. Jayanthakumaran and Liu (2012) analyze the trade openness on growth and environment for China. Their results provide that the scale effect dominates the technique effect for $\mathrm{SO}_{2}$ and the industrial per capita chemical oxygen demand (COD). Jalil and Mahmud (2009) also examine the relationship between carbon emission, income and foreign trade for China. They confirm EKC and find positive but insignificant impact of trade on $\mathrm{CO}_{2}$ emissions. Similarly, Haisheng et al. (2005) find no direct impact of trade on EKC for China for the period 1990-2002.

Another approach for EKC analyzis is observing the impact of foreign direct investment (FDI) on the EKC model. The relationship between $\mathrm{CO}_{2}$ emissions, energy consumption, FDI and GDP is discussed in several studies by including different combinations of these variables (such as $\mathrm{He}$ et al. (2012), Lee (2013), Linh and Lin (2015)). By using cointegration analyzis and Granger causality test, some studies show that there is a long run relationship between the aforementioned variables and $\mathrm{CO}_{2}$ for Sub-Saharan African countries (Kivyiro and Arminen, 2014). This is also the case for Malaysia, Indonesia and Thailand of ASEAN-5 countries (Chandran and Tang, 2013). Furthermore, Pao and Tsai (2011) observe strong bidirectional causality between emission and FDI in BRIC (Brasil, Russia, India and China) countries for the period 1980-2007. On the other hand, Kim and Baek (2011) use the autoregressive distributed lag (ARDL) technique and cointegration test for a sample of 40 countries for the period 1971-2005. The results state that although income and energy have an impact on environment in the short run, FDI has no impact in the short run, yet a little impact in the long run. Similarly, Antweiler et al. (2001) use FDI as an additional explanatory variable and find a small effect of FDI on pollution level for 43 countries. However, Omri et al. (2014) develop a panel data model with a sample of 54 countries over the period 1990-2001. They observe a bidirectional causality between FDI inflows and $\mathrm{CO}_{2}$ emissions.

Vast literature investigating the EKC hypothesis for Turkey includes the basic concept of EKC that refers to the relationship between the indicators of environment and income without taking other factors such as trade, foreign direct investment or factor endowment. Some of these papers use energy consumption as a dependent variable to test the causality relation with income, while others use $\mathrm{CO}_{2}$ emissions. Soytas et al. (2001) search the causality relationships between energy consumption and GDP. Using the data for the period 1960-1995, they observe a unidirectional causality arising from energy consumption to GDP. Similarly, Lise and Van Montfort (2007) test the causality relationship between energy consumption and GDP. Their study shows a unidirectional causality running from GDP to energy consumption for the period 1970-2003, however, no support for EKC. Erdal et al. (2008) use the data of energy consumption and gross national product (GNP) for the period from 1970 to 2006 and they find a bidirectional causality between these two variables. On the other hand, Altinay and Karagol (2004) do not observe any causality between energy consumption and GDP in Turkey. Similarly, the study of Jobert and Karanfil (2007) also shows that there is not any linear cointegration relationship between energy consumption and real GNP in Turkey for the period 1960-2003. As another perspective for the relationship between energy consumption and economic growth, Say and Yucel (2006) develop a multi-linear regression model by using GNP and population growth. The results show that there are strong relationships between total energy consumption and these two variables. Basar and Temurlenk (2007) use $\mathrm{CO}_{2}$ emissions and GDP data for the period 1950-2000 and they reject the EKC for Turkey, rather they find an inverted $\mathrm{N}$-shaped relation. However, Omay (2013) observes N-shaped relation by using the same variables for the period 1980-2009. Similarly, Akbostanc1 et al. (2009) test the EKC hypothesis for 58 provinces in Turkey for the period 1992-2001. They find no evidence for EKC, but an $\mathrm{N}$-shaped relationship. In addition, they observe a monotonically increasing relationship between $\mathrm{CO}_{2}$ emissions and GDP.

Other studies extend EKC analyzis for Turkey by using additional variables in their models. Soytas and Sari (2009) analyze the effect of energy consumption and GDP on $\mathrm{CO}_{2}$ emissions by controlling labor and gross fixed capital investment. According to their results, there is no long run causality between $\mathrm{CO}_{2}$ emission and GDP. Moreover, Ozturk and Acaravc1 (2010) investigate the causality relationships between $\mathrm{CO}_{2}$ emissions, energy consumption and GDP. They find a long run relationship between these variables, and argue that EKC hypothesis is not valid for Turkey. Halicioglu (2008) also investigates these variables for the period 1960-2005. However, he adds the data of foreign trade to the model. He finds two Granger causality relationships. First one is between $\mathrm{CO}_{2}$ emissions and energy consumption and second one is between $\mathrm{CO}_{2}$ emissions and income. According to his results, although there are long run relationships 
between $\mathrm{CO}_{2}$ emissions and all variables, income is the main determinant to explain the emissions in Turkey.

In 2001, Turkey has experienced the worst economic turbulence of her history. Starting with the post-crisis period, it has been one of the most attractive locations for foreign investment inflows due to its economic transformation that has been supported by dynamic market conditions and population, as well as regulations and standards (YOIKK, 2013). Furthermore, after 2008 global economic crisis, some regions of the world (especially European Union) have lost their attraction for investors because of the huge amount of debt stocks, while developing regions including Brazil, Russia, China have become the main engine for the global growth (YOIKK, 2013). Although, Turkey was affected by this global crisis and decreasing foreign investment inflows in these years, according to the Central Bank of the Republic of Turkey, FDI inflows to Turkey reached 12.5 USD billion in 2014. These FDI flows are generally unevenly distributed between sectors. In 2013, total share in manufacturing sector, electricity, gas and water supply, finance and real estate shows almost three quarters of total FDI (UNCTAD, 2014).

Based on the Kyoto Protocol, for protection of global environment, countries targeted to control emission at 5\% between 1990 and 2008 as a first commitment period. Countries (including Turkey), which have not participated in the Kyoto Protocol, have reached 94.2\% changes in $\mathrm{CO}_{2}$ emissions from fuel combustion as a group, while others have accomplished $-4.7 \%$ of Kyoto target. In Turkey, emission rose from 126.9 in 1990 to $285.7 \mathrm{MtCO}_{2}$ in 2011, an increase of $125.1 \%$ (IEA, 2013). Although there are some measures for environmental protection and important changes in energy supply, emissions are still increasing in Turkey due to economic growth. As a result, foreign investment inflows, especially in manufacturing and energy sectors, can be considered significant determinants for the emissions.

Our motivation sprouts exactly at this point. In this study, we attempt to test the EKC hypothesis for Turkey in the presence of FDI and trade indicators, which is the main contribution of this study. Although the literature on whether EKC is valid in Turkey is vast, it does not involve the potential effects of FDI and trade. Given that it has now been more than three decades since the country is liberalized the economy, it is crucial to see the impact of foreign investment and trade on the environment. Our study is based on Lau et al. (2014). In their study, they combine the variables of $\mathrm{CO}_{2}$ emissions, GDP, FDI and trade openness in a time series model for Malaysia over the period 19702008. They use ARDL technique and Granger causality test to analyze the model. Their results show that the EKC hypothesis is valid in both the short and the long run. In addition, they show that FDI and trade affect $\mathrm{CO}_{2}$ emissions directly and also indirectly through the economic growth in the short run. Following Lau et al. (2014), we examine the short and long run relationship and also causality relationship between these variables.

The exact structure of our econometric model and the data used will be described in the next section, with the scatter plots and other figures spelt out in the appendix. In section 2, we shall carry out discussing and evaluating the results. Finally, in last section, we shall make some concluding remarks.

\section{Data and methodology}

In this section, we shall present the data and the model framework and set up the appropriate tests to run. The first section will cover the Augmented Dickey Fuller test, cointegration test and regression analyzis. This will be followed by Granger causality test.

1.1. Model and data. We use annual data of GDP, FDI net inflows and trade openness to observe the relationship between $\mathrm{CO}_{2}$ emissions and these variables. The data that are taken from the World Bank database and Central Bank of the Republic of Turkey include the period from 1974 to 2010 for Turkey. We take natural logarithmic form of GDP and FDI inflows to make differences smaller and reduce the effect of heteroscedasticity problem. By extending the EKC analyzis, we develop the following model.

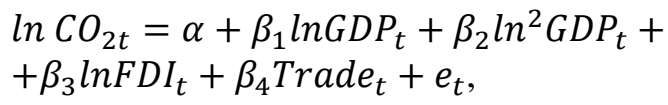

where $\operatorname{lnCO} \mathrm{CO}_{2 t}$ is the logarithmic function of $\mathrm{CO}_{2}$ emissions (metric tons per capita), $\ln G D P_{t}$ and $\ln G D P_{t}^{2}$ are the logarithmic functions of GDP (constant-price Turkish lira) and its square, $\ln F D I_{t}$ is the logarithmic function of FDI net inflows (current US\$) and finally, Trade $_{t}$ is trade openness which is represented by the total share of export and import in GDP.

When we look at the scatter plots (Figure 1 in Appendix) between $\mathrm{CO}_{2}$ emissions and other explanatory variables, it is seen that $\mathrm{CO}_{2}$ emissions are decreasingly growing when GDP increases. On the other hand, FDI inflows display a linear relationship with some deviations. Trade openness exhibits a positive linear relationship with more deviations than FDI does. According to Figure A.1 (see Appendix), when FDI flows, GDP and trade openness increase, $\mathrm{CO}_{2}$ emission increases. Furthermore, we include $\mathrm{GDP}^{2}$ into the model to check whether $\mathrm{CO}_{2}$ emissions decrease after a certain point of GDP or not. In other 
words, we intend to check the existence of an inverse U-shaped relationship for Turkey stated by EKC theory. Hence, $\beta_{2}$ is expected to have a negative sign. Given the above structure, we attempt to explain the relationships between the variables for the short and long run by using the model given by equation (1).

Using equation (1) might result in a spurious regression because of the non-stationary variables. Therefore, unit root test, which is one of the most common stability testing techniques, should be performed in order to develop a more appropriate econometric model. The below tables show the unit root test analyzis for all variables in the model.

Table 1. Unit root test for all variables

\begin{tabular}{|l|c|c|c|c|}
\hline \multicolumn{1}{|c|}{ Variables } & Lag length & $\mathrm{T}$ & $\mathrm{T}_{\mathrm{m}}$ & $\mathrm{T}_{\mathrm{t}}$ \\
\hline $\mathrm{LnCO}_{2}$ & 0 & 2.614 & -0.822 & -2.597 \\
\hline $\mathrm{D}\left(\mathrm{LnCO}_{2}\right)$ & 0 & $-4.823^{*}$ & $-5.829^{*}$ & $-5.737^{*}$ \\
\hline $\mathrm{LnGDP}$ & 0 & 3.575 & 0.580 & -1.723 \\
\hline $\mathrm{D}(\mathrm{LnGDP})$ & 0 & $-4.509^{*}$ & $-5.891^{*}$ & $-6.036^{*}$ \\
\hline $\mathrm{Ln}^{2} \mathrm{GDP}$ & 0 & 3.581 & 0.632 & -1.672 \\
\hline $\mathrm{D}\left(\mathrm{Ln}{ }^{2} \mathrm{GDP}\right)$ & 0 & $-4.494^{*}$ & $-5.874^{*}$ & $-6.039^{*}$ \\
\hline $\mathrm{LnFDI}$ & 0 & 0.957 & -0.908 & $-4.212^{*}$ \\
\hline $\mathrm{D}(\mathrm{LnFDI})$ & 0 & $-8.311^{*}$ & $-8.535^{*}$ & $-8.489^{*}$ \\
\hline Trade & 1 & 0.649 & -1.269 & -2.939 \\
\hline $\mathrm{D}($ Trade $)$ & 1 & $-5.222^{*}$ & $-4.725^{*}$ & $-4.705^{*}$ \\
\hline
\end{tabular}

*Significant according to MacKinnon (1996) one-sided 0.01\% pvalue.

Note: $\mathrm{LnCO}_{2}$ LnGDP Ln$^{2} \mathrm{GDP}$ LnFD Trade are I(1).
We use Augmented Dickey Fuller test to prevent autocorrelation problem that is caused by using lagged variables in the model. According to the Augmented Dickey Fuller test results, the null hypothesis that claims that first-degree differences of all variables have unit root should be rejected. Therefore, the model should be developed by using the first-degree differences of the variables. If there is no cointegration, we get the following model:

$$
\begin{aligned}
& \Delta\left(\ln C O_{2 t}\right)=\alpha+\beta_{1} \Delta \ln G D P_{t}+\beta_{2} \Delta \ln G D P_{t}^{2}+ \\
& \beta_{3} \Delta \ln F D I_{t}+\beta_{4} \Delta \text { Trade }_{t}+e_{t}
\end{aligned}
$$

The first-degree differences of variables that are obtained from equation (1) are denoted by the Greek letter " $\Delta$ ". Having more than two variables can create a possibility of having more than one cointegration vector, i.e., the long run relationship. If there is cointegration between variables, we cannot use equation (2). Hence, we shall check long run and cointegration relationship. Before running any test for cointegration analyzis, we investigate appropriate lag length by using Vector Autoregressive (VAR) modeling techniques. Considering Akaike and Schwarz criteria, the optimal lag length is determined as "1".

GDP, FDI and $\mathrm{CO}_{2}$ emissions may move together in the long run. That is why we shall now perform long run model. According to the results, long run equation is obtained as follows:

\begin{tabular}{|c|c|c|c|c|}
\hline \multicolumn{5}{|l|}{ Dependent variable: $\mathrm{LNCO}_{2}$} \\
\hline \multicolumn{5}{|l|}{ Method: least squares } \\
\hline \multicolumn{5}{|l|}{ Sample: 19742010} \\
\hline \multicolumn{5}{|l|}{ Included observations: 37} \\
\hline \multicolumn{5}{|c|}{ White heteroskedasticity - consistent standard errors \& covariance } \\
\hline Variable & Coefficient & Std. Error & t-statistic & Prob. \\
\hline C & -283.436 & 29.131 & -9.730 & 0.000 \\
\hline LNGDP & 30.755 & 3.236 & 9.505 & 0.000 \\
\hline LNGDP2 & -0.831 & 0.090 & -9.246 & 0.000 \\
\hline LN(FDI) & 0.011 & 0.010 & 1.107 & 0.277 \\
\hline TRADE & 0.002 & 0.001 & 1.756 & 0.089 \\
\hline R-squared & 0.982 & Mean dependent var & & 0.969 \\
\hline Adjusted R-squared & 0.980 & S.D. dependent var & & 0.289 \\
\hline S.E. of regression & 0.041 & Akaike info criterion & & -3.418 \\
\hline Sum squared resid & 0.054 & Schwarz criterion & & -3.200 \\
\hline Log likelihood & 68.227 & Hannan-Quinncriter & & -3.341 \\
\hline F-statistic & 436.082 & Durbin-Watson stat & & 1.171 \\
\hline Prob(F-statistic) & 0.000 & & & \\
\hline
\end{tabular}

Table 2. Long run equation

Table 2 clearly shows long run relationship. It can be seen that $\mathrm{GDP}^{2}$ has a negative sign as expected. In this case, are expected $\mathrm{CO}_{2}$ emissions to increase when GDP, Trade and FDI increase, while $\mathrm{GDP}^{2}$ decreases in the long run. Moreover, we calculate the turning point of environmental Kuznets curve from exp $(30.755 /(2 * 0.831))$ and find approximately 108.777.327 Turkish lira. 
This will be discussed in the next section.

After the estimation of long run model, we obtain residuals and test availability of unit root in accordance with the Engle-Granger (1969) cointegration method (see Table 3). The results of unit root test show that there is a cointegration relationship between variables.

Table 3. Cointegration test results

\begin{tabular}{|c|c|c|c|}
\hline \multicolumn{4}{|c|}{ Null hypothesis: ER has a unitroot } \\
\hline \multicolumn{4}{|l|}{ Exogenous: none } \\
\hline \multicolumn{4}{|c|}{ Lag length: 0 (automatic - based on SIC, $\max$ lag=9) } \\
\hline \multicolumn{2}{|c|}{ Augmented Dickey-Fuller test statistic } & t-statistic & Prob.* \\
\hline \multirow{4}{*}{ Test critical values: } & $1 \%$ level & -3.688 & \multirow{4}{*}{0.000} \\
\hline & $5 \%$ level & -2.631 & \\
\hline & $10 \%$ level & -1.950 & \\
\hline & & -1.611 & \\
\hline
\end{tabular}

Eventually, when we add the long run relationship into the short run relationship equation (2) and run this final model, we get the following model:

$\Delta \operatorname{lnCO} \mathrm{O}_{2 t}=\alpha+E R(-1)+\sum_{i=0}^{k} \beta_{1 i} \Delta \ln G D P_{t-i}+$ $+\sum_{i=0}^{k} \beta_{2 i} \Delta \ln G D P_{t-i}{ }^{2} \sum_{i=0}^{k} \beta_{3 i} \Delta \ln F D I_{t-i}+$

$+\sum_{i=0}^{k} \beta_{3 i} \Delta$ Trade $_{t-i}+e_{t}$.

The results of this test will be shown and discussed in the following section.

\section{Results and discussions}

After unit root tests and cointegration analyzes, we find the general equation. Next, we run this equation for regression analyzes in E-views software program. The results are shown in Table 4.

According to the test results, model and coefficients of FDI, GDP and $\mathrm{GDP}^{2}$ are statistically significant at $10 \%$ significance level. Trade has no significant effect on $\mathrm{CO}_{2}$ emission in the short run. It is also seen that goodness of fit is sufficiently high. Based on the $\mathrm{R}^{2}$ value, we see that the model with first difference levels of Trade, FDI, GDP and GDP $^{2}$ can explain $61 \%$ of the variation in $\mathrm{CO}_{2}$ emissions. In addition, the error correction term (ER) is -0.37 . This indicates that when there is a deviation in the equilibrium level of $\mathrm{CO}_{2}$, this deviation adjusts at the level of $37 \%$ after one year. In this case, the total adjustment process takes almost three years. ER also represents the long run relationship. Since the coefficient of ER is negative and statistically significant, $\mathrm{CO}_{2}$ emission has long run relationships with GDP, GDP², FDI and Trade.

Table 4. Regression test results

\begin{tabular}{|c|c|c|c|c|}
\hline \multicolumn{5}{|l|}{ Dependent variable: D(LNCO2) } \\
\hline \multicolumn{5}{|l|}{ Method: least squares } \\
\hline \multicolumn{5}{|l|}{ Sample (adjusted): 19752010} \\
\hline \multicolumn{5}{|c|}{ Included observations: 36 after adjustments } \\
\hline \multicolumn{5}{|c|}{ White heteroskedasticity - consistent standard errors \& covariance } \\
\hline Variable & Coefficient & Std. Error & t-Statistic & Prob. \\
\hline $\mathrm{C}$ & 0.020 & 0.010 & 1.994 & 0.055 \\
\hline $\mathrm{D}(\mathrm{LGSMH})$ & 0.984 & 0.175 & 5.634 & 0.000 \\
\hline $\mathrm{D}(\mathrm{LGSMH})^{\wedge} 2$ & -7.534 & 3.172 & -2.375 & 0.024 \\
\hline $\mathrm{D}(\mathrm{LNFDI})$ & -0.012 & 0.006 & -1.789 & 0.084 \\
\hline $\mathrm{D}(\mathrm{TRADE})$ & 0.002 & 0.001 & 1.402 & 0.171 \\
\hline $\mathrm{ER}(-1)$ & -0.376 & 0.147 & -2.556 & 0.016 \\
\hline R-squared & 0.610 & Mean dependent var & & 0.026 \\
\hline Adjusted R-squared & 0.545 & S.D. dependent var & & 0.052 \\
\hline S.E. of regression & 0.035 & Akaike info criterion & & -3.709 \\
\hline Sum squared resid & 0.037 & Schwarz criterion & & -3.446 \\
\hline Log likelihood & 72.770 & Hannan-Quinncriter & & -3.617 \\
\hline F-statistic & 9.388 & Durbin-Watson stat & & 1.930 \\
\hline Prob(F-statistic) & 0.000 & & & \\
\hline
\end{tabular}

White Obs*R-squared 3.355 Prob. Chi-Square(5) 0.645.

ARCH Obs*R-squared 1.422Prob. Chi-Square(1) 0.233.

Jarque-Bera 0.220 Prob. 0.890.

Breusch-Godfrey Serial Correlation LM Chi-Square(2)0.189, Prob. 0.909.

We find that Trade affects the $\mathrm{CO}_{2}$ emissions positively in long run, but insignificantly in short run. Moreover, it is found that FDI affects $\mathrm{CO}_{2}$ emissions negatively in the short run, but positively in the long run. In the model, there are both GDP and $\mathrm{GDP}^{2}$, so we use Wald test 
statistics to see the net short run effect. According to the Wald test results, there is also short run effect of GDP on $\mathrm{CO}_{2}$ emissions (ChiSquare $=4.539$, Pr. $=0.033$ ). This means EKC is also valid in the short run. We also calculate the turning point of environmental Kuznets curve for the short run and find 0.065 (from 0.984/ (2* 7.534) formula).

We shall now carry on with the Granger test to see the causality relationship between variables.

2.1. Granger causality analyzis. We use Granger causality test technique to investigate the causality relationship between $\mathrm{CO}_{2}$ emissions, GDP, FDI inflows and trade openness. The Granger causality test, first used by Granger (1969), is a statistical hypothesis test to see if one time series can forecast another. The test results of Granger causality test are shown below.

Table 5. Causality analysis test results

\begin{tabular}{|c|c|c|c|}
\hline \multicolumn{4}{|l|}{ Pairwise Granger causality tests } \\
\hline \multicolumn{4}{|l|}{ Sample: 19742010} \\
\hline \multicolumn{4}{|l|}{ Lags: 1} \\
\hline Null hypothesis: & Obs & F-statistic & Prob. \\
\hline LNFDI does not Granger cause $\mathrm{LNCO}_{2}$ & 36 & 4.310 & 0.046 \\
\hline $\mathrm{LNCO}_{2}$ does not Granger cause LNFDI & 36 & 13.757 & 0.001 \\
\hline LNGDP does not Granger cause $\mathrm{LNCO}_{2}$ & 36 & 0.366 & 0.549 \\
\hline $\mathrm{LNCO}_{2}$ does not Granger cause LNGDP & 36 & 0.071 & 0.791 \\
\hline TRADE does not Granger cause $\mathrm{LNCO}_{2}$ & 36 & 8.771 & 0.006 \\
\hline $\mathrm{LNCO}_{2}$ does not Granger cause TRADE & 36 & 1.181 & 0.285 \\
\hline DLNFDI does not Granger cause $\mathrm{DLNCO}_{2}$ & 35 & 0.000 & 0.985 \\
\hline $\mathrm{DLNCO}_{2}$ does not Granger cause DLNFDI & 35 & 0.434 & 0.515 \\
\hline DLNGDP does not Granger cause $\mathrm{DLNCO}_{2}$ & 35 & 0.247 & 0.623 \\
\hline $\mathrm{DLNCO}_{2}$ does not Granger cause DLNGDP & 35 & 1.161 & 0.289 \\
\hline DTRADE does not Granger cause $\mathrm{DLNCO}_{2}$ & 35 & 0.227 & 0.637 \\
\hline $\mathrm{DLNCO}_{2}$ does not Granger cause DTRADE & 35 & 0.052 & 0.821 \\
\hline
\end{tabular}

Analogous to Soytas and Sari (2009), we find no Granger causality relationship between $\mathrm{CO}_{2}$ emissions and GDP. On the other hand, we find a bidirectional causality relationship between FDI and $\mathrm{CO}_{2}$ emissions. As a result, when a shock occurs in one of these two variables, it is expected to affect the other variable. Moreover, there is a unidirectional causality running from Trade to $\mathrm{CO}_{2}$ emissions. Therefore, a shock in Trade results in another shock in $\mathrm{CO}_{2}$ emissions. Besides all these, there is not any short run causality relation in the model.

In his study, Halicioglu (2008) finds that the sign of the coefficient of GDP2 is negative, hence, this may be an indication for the validity of the EKC hypothesis in Turkey. However, he refers to graphical representation of the data that show the relationship between $\mathrm{CO}_{2}$ emissions and GDP; and he claims that there is no evidence for EKC, although his test results prove opposite. Like Halicioglu (2008), we use cointegration methods and find a negative coefficient for GDP ${ }^{2}$ in our regression model. In addition, we use restriction method to see the total combined effect of GDP and $\mathrm{GDP}^{2}$ on $\mathrm{CO}_{2}$ emissions. According to the results, this total effect is not zero ${ }^{1}$. This supports the findings of our regression model, which show an inverted U-

${ }^{1}$ LR test for binding restrictions (rank = 1): Chi-square (1): 90.48 , Probability: 0.000 . shaped relationship between $\mathrm{CO}_{2}$ emissions and GDP. Therefore, our study provides an evidence for EKC hypothesis and we can say that after a certain point, $\mathrm{CO}_{2}$ emissions decrease with GDP. These findings are also in line with Lau et al. (2015) and the references therein. For EKC to be realized in Turkey, the GDP should be 108.777.327 TL. After this level, we expect a reduction in emissions.

The turning point in the short run is 0.065 . This means that EKC occurs in Turkey in the short run if the annual growth rate is $6.5 \%$. The average growth rate in Turkey has been $4.52 \%$ during 2010-2015. Within our data period (i.e., 1974-2010), it was $4 \%$.

Based on the CUSUM of Squares analyzis, we do not observe any situation that conflicts with the stability. Moreover, according to the Ramsey RESET tests statistics, there is no specification error in our model (for Ramsey RESET, F = 0.41, Pr. = 0.52). Therefore, it can be said that predictions and inferences are consistent. It would not be wrong to say that the final econometric model has quite explanatory effect.

According to the Granger causality test, there is a bidirectional causality between foreign direct investment and $\mathrm{CO}_{2}$ emissions in the long run. This means that an increase in FDI leads to an increase in $\mathrm{CO}_{2}$ emissions. Similarly, an increase in $\mathrm{CO}_{2}$ emissions results in an increase in FDI. An increase in 
$\mathrm{CO}_{2}$ emissions may create a perception of lack regulations for pollution. This represents an attractive environment image for foreign investment and, therefore, may increase FDI. In addition, the results show that there is a unidirectional causality coming from trade to $\mathrm{CO}_{2}$ emissions. A natural proposition out of these results would be putting up environmentally stricter regulations to eliminate the social costs on welfare of increased amount of FDI activities and trade.

The foreign direct investment seeks countries in which they can perform production activities in more favorable conditions and achieve more profits. The location decision of foreign direct investment is influenced by structural features and policy decisions of the host countries. This may result in a race between countries to attract foreign direct investment. For this reason, countries may design their policies in favor of FDI and impose less strict environmental regulations. According to the study of Low and Yeates (1992), polluting industries have been moved through foreign direct investments to the countries with low level of environmental standards during the 1970s and $1980 s^{2}$. Similarly, Xing and Kolstad (2002) analyze the relationship between FDI and environmental regulations. It is found that there is a negative relationship between FDI and strict environmental regulations for pollution-intensive industries such as chemical and metal. In addition, Kalamova and Johnstone (2011) also examine the FDI inflows by using the data from 27 OECD source countries and 99 host countries for the period 2001-2007. Their results show that there is an inverse U-shaped relationship between the lax environmental standards and FDI inflows for both developed and developing countries. It means that when the environmental standards fall below a certain level, countries lose their ability or attractiveness to attract investments. On the other hand, Jorgenson (2009) finds that there is a positive relationship between $\mathrm{CO}_{2}$ emissions and foreign direct investment in the secondary sector in less developed countries by using the data of 19752000. This implies that foreign capitals especially operating in manufacturing industry are less ecoefficient and, hence, they tend to be more harmful for the environment in those countries. Basically, these studies show that many countries have faced the trade-off between attracting foreign direct investment and risking environment. According to our results, which present a significant and positive relationship between foreign direct investment

${ }^{2}$ For a theoretical background, see Kayalica and Lahiri (2005) and the references there in. inflows and $\mathrm{CO}_{2}$ emission, Turkey seems to be one of these countries. Therefore, to protect environment and ensure sustainable growth, the government should take some measures in terms of compositions and operations of foreign investment. This concern also should be taken into account while designing trade policies, as there is a positive relationship between trade and $\mathrm{CO}_{2}$ emissions in Turkey.

\section{Conclusions}

In this study, we extend the EKC analyzis by adding foreign direct investment and trade parameters for Turkey. By using annual data for the period 19742010, we apply cointegration and causality test techniques to analyze the short and long run effects and causality relationships. We find an inverted Ushaped relationship between $\mathrm{CO}_{2}$ emissions and GDP. Therefore, our results support the EKC hypothesis for Turkey.

GDP, GDP ${ }^{2}$, FDI and trade openness have an impact on $\mathrm{CO}_{2}$ emissions in the long run. Trade affects $\mathrm{CO}_{2}$ emissions positively in the long run, but insignificantly in the short run, while FDI affects $\mathrm{CO}_{2}$ emissions negatively in the short run, but positively in the long run. We also find a bidirectional causality relationship between $\mathrm{CO}_{2}$ emission and FDI, and a unidirectional causality running from trade openness to $\mathrm{CO}_{2}$ emissions for Turkey.

Trade and investment liberalization are often thought to create pollution heavens by developing channels through which polluting industries may shift to less developed countries. Turkey, after almost two decades of import substitution industrialization period, turned its face to export oriented growth strategies in 1980 and gradually liberalized its markets throughout the years. Eventually, the trade volume has significantly increased. On the other hand, Turkey has not attracted a significant amount of foreign direct investment until after 2003. Since then, attracting foreign direct investment inflows has been a major issue for the government. Our results imply that the Turkish government needs to be cautious while designing policies regarding both trade and investment due to environmental externalities. Instead of more foreign direct investment and higher volume of trade, the government shall prefer an environmentally sustainable foreign direct investment and trade.

The bidirectional causality between foreign direct investment and $\mathrm{CO}_{2}$ implies that not only foreign direct investment causes $\mathrm{CO}_{2}$ emissions, but increased emissions also attract FDI. In addition, 
bidirectional causality between trade and $\mathrm{CO}_{2}$ shows that trade increases emissions. These results are in parallel with the view that trade and investment liberalization leads to pollution havens through the migration of polluting industries to less developed countries or to countries with lax environmental regulations in general. Together, these results imply that there is a room for stricter environmentalrelated policies in Turkey. The policy alternatives to improve the environment and achieve a greener economy that are dedicated to regulate trade and investment atmosphere in a country are paramount. From product standards to process standards, from taxes to subsidies one could name many of such policy tools. Besides these environmental policy tools, there are also trade and investment measures that could also improve the environment. Amongst others, liberalization of environmental goods and services, protection of investments in green market building activities through trade-related investment agreements are some of them. Obviously, these policies would need to be in coordination with international rules, policies and institutions, such as World Trade Organization (WTO), UNCTAD, United Nations Environment Programme (UNEP) and Multilateral Environmental Agreements (MEAs), etc.

The results of this study underline the importance of the need to further investigate the role of trade and foreign direct investment on the environment by focusing on the polluting industries in trade and investment rather than using the general figures of these parameters. Needless to say, this requires a more detailed data set, in particular regarding the foreign direct investment.

\section{References}

1. Akbostanc1, E., Türüt-Așık, S., Tunç, G.I. (2009). The relationship between income and environment in Turkey: Is there an environmental Kuznets curve? Energy Policy, 37, pp. 861-867.

2. Altinay, G., Karagol, E. (2004). Structural break, unit root, and the causality between energy consumption and GDP in Turkey, Energy Economics, 26, pp. 985-994.

3. Antweiler, W., Copeland, B.R., Taylor, M.S. (2001). Is free trade good for the environment? The American Economic Review, 91, pp. 877-908.

4. Bagliani, M., Bravo, G., Dalmazzone, S. (2008). A consumption-based approach to environmental Kuznets curves using the ecological footprint indicator, Ecological Economics, 65, pp. 650-651.

5. Barrett, S. (2000). Trade and the environment: local versus multilateral reforms, Environment and Development Economics, 5, pp. 349-359.

6. Basar, S., Temurlenk, M.S. (2007). Environmental Kuznets curve: An empirical analyzis for Turkey, Ataturk University Journal of Economics and Administrative Sciences, 21, pp. 1-12.

7. Chandran, V.G.R., Tang, C.F. (2013). The impacts of transport energy consumption, foreign direct investment on $\mathrm{CO}_{2}$ emission in ASEAN-5 economies, Renewable and Sustainable Energy Reviews, 24, pp. 445-453.

8. Cole, M.A., Elliott, R.J.R. (2003). Determining the trade-environment composition effect: the role of capital, labor and environmental regulations, Journal of Environmental Economics and Management, 46, pp. 363-383.

9. Dijkgraaf, E., Vollebergh, H.R.J. (2005). A test for parameter homogeneity in $\mathrm{CO}_{2}$ panel EKC estimations, Environmental and Resource Economics, 32, pp. 229-239.

10. Erdal, G., Erdal, H., Esengün, K. (2008). The causality between energy consumption and economic growth in Turkey, Energy Policy, 36, pp. 3838-3842.

11. Frankel, J.A., Rose, A.K. (2005). Is Trade Good or Bad for the Environment? Sorting Out the Causality, The Review of Economics and Statistics, 87, pp. 85-91.

12. Galeotti, M., Manera, M., Lanza, A. (2006). On the robustness of robustness checks of the environmental Kuznets curve, Fondazione Eni Enrico Mattei Working Papers, 22.

13. Granger, C.W.J. (1969). Investigating causal relations by econometric models and cross-spectral methods, Econometrica, 37, pp. 424-438.

14. Grossman, G.M., Krueger, A.B. (1995). Economic growth and the environment, The Quarterly Journal of Economics, 110 , pp. 353-377.

15. Haisheng, Y., Jia, J., Yongzhang, W., Shugong, W. (2005). The impact on environmental Kuznets curve by trade and foreign direct investment in China, Chinese Journal of Population, Resources and Environment, 3, pp. 14-19.

16. Halicioglu, F. (2008). An econometric study of $\mathrm{CO}_{2}$ emissions, energy consumption, income and foreign trade in Turkey, Energy Policy, 37, pp. 1156-1164.

17. He, W., Gao, G., Wang, Y. (2012). The relationship of energy consumption, economic growth and foreign direct investment in Shanghai, Advances in Applied Economics and Finance (AAEF), 3, pp. 507-512.

18. Holtz-Eakin, D., Selden, T.M. (1995). Stoking the fires? $\mathrm{CO}_{2}$ emissions and economic growth, Journal of Public Economics, 57, pp. 85-101.

19. IEA, International Energy Agency. (2013). $\mathrm{CO}_{2}$ Emissions From Fuel Combustion Highlights, 2013 Edition.

20. Jalil, A., Mahmud, S.F. (2009). Environment Kuznets curve for $\mathrm{CO}_{2}$ emissions: A cointegration analyzis for China, Energy Policy, 37, pp. 5167-5172. 
21. Jayanthakumaran, K., Liu, Y. (2012). Openness and the environmental Kuznets Curve: Evidence from China, Economic Modelling, 29, pp. 566-576.

22. Jobert, T., Karanfil, F. (2007). Sectoral energy consumption by source and economic growth in Turkey, Energy Policy, 35 , pp. 5447-5456.

23. Jorgenson, A.K. (2009). The Transnational organization of production, the scale of degradation, and Eco efficiency: A study of carbon dioxide emissions in Less-Developed countries, Human Ecology Review, 16, pp. 64-74.

24. Kacar, S.B., Kayalica, M.O. (2014). Environmental Kuznets Curve and sulfur emissions: A comparative econometric analyzis, Environmental Economics, 5, pp. 8-20.

25. Kalamova, M., Johnstone, N. (2011). Environmental policy stringency and foreign direct investment, $O E C D$ Environment Working Papers, 33.

26. Kayalica, M.O., Lahiri S. (2005). Strategic environmental policies in the presence of foreign direct investment, Environmental and Resource Economics, 30, pp. 1-21.

27. Kim, H.S., Baek, J. (2011). The Environmental consequences of economic growth revisited, Economics Bulletin, 31, pp. 1198-1211.

28. Kivyiro, P., Arminen, H. (2014). Carbon dioxide emission, energy consumption, economic growth and foreign direct investment: Causality analyzes for Sub-Saharan Africa, Energy, 74, pp. 595-606.

29. Lau, L.S, Choong, C.K., Eng, Y.K. (2014). Investigation of the environmental Kuznets curve for carbon emissions in Malaysia: Do foreign direct investment and trade matter? Energy Policy, 68, pp. 490-497.

30. Lee, J.W. (2013). The contribution of foreign direct investment to clean energy use, carbon emissions and economic growth, Energy Policy, 55, pp. 483-489.

31. Linh, D.H., Lin, S.M. (2015). Dynamic causal relationship among $\mathrm{CO}_{2}$ emissions, energy consumption, economic growth and FDI in the most populous Asian countries, Advances in Management \& Applied Economics, 5, pp. 69-88.

32. Lise, W., Van Montfort, K. (2007). Energy consumption and GDP in Turkey: Is there a co-integration relationship? Energy Economics, 29, pp. 1166-1178.

33. Low, P., Yeats, A. (1992). Do dirty industries migrate? In Low, P. (Ed.), International Trade and the Environment, the World Bank, Washington DC, pp. 89-103.

34. Omay, R.E. (2013). The Relationship between Environment and Income: Regression Spline Approach, International Journal of Energy Economics and Policy, 3, pp. 52-61.

35. Omri, A., Nguyen, D.K., Rault, C. (2014). Causal interactions between $\mathrm{CO}_{2}$ emission, FDI and economic growth: Evidence from dynamic simultaneous-equation models, Economic Modelling, 42, pp. 382-389.

36. Ozturk, I., Acaravc1, A. (2010). $\mathrm{CO}_{2}$ emission, energy consumption and economic growth in Turkey, Renewable and Sustainable Energy Reviews, 14, pp. 3220-3225.

37. Pao, H.T., Tsai, C.M. (2011). Multivariate Granger causality between $\mathrm{CO}_{2}$ emissions, energy consumption, FDI (foreign direct investment) and GDP (gross domestic product): Evidence from a panel of BRIC (Brazil, Russian Federation, India, and China) countries, Energy Policy, 36, pp. 685-693.

38. Perman, R., Stern, D.I. (2003). Evidence from panel unit root and cointegration tests that the Environmental Kuznets Curve does not exist, The Australian Journal of Agricultural and Resource Economics, 47, pp. 325-347.

39. Roberts, J.T., Grimes, P.E. (1997). Carbon Intensity and Economic Development 1962-91: A Brief Exploration of the Environmental Kuznets Curve, World Development, 25, pp. 191-198.

40. Say, N.P., Yucel, M. (2006). Energy consumption and $\mathrm{CO}_{2}$ emission in Turkey: Empirical analyzis and future projection based on an economic growth, Energy Policy, 34, pp. 3870-3876.

41. Soytas, U., Sari, R. (2009). Energy consumption, economic growth and carbon emission: Challenges faced by an EU candidate member, Ecological Economics, 68, pp. 1667-1675.

42. Soytas, U., Sari, R., Ozdemir, O. (2001). Energy consumption and GDP relation in Turkey: A cointegration and vector error correction analyzes. Economies and business in transition: facilitating competitiveness and change in the global environment proceeding, Global Business and Technology Association, pp. 838-844.

43. Stern, D.I. (1998). Progress on the environmental Kuznets curve? Environment and Development Economics, 3, pp. 173-196.

44. Stern, D.I., Common, M.S. (2001). Is there an environmental Kuznets curve for sulfur? Journal of Environmental Economics and Management, 41, pp. 162-178.

45. Suri, V., Chapman, D. (1998). Economic growth, trade and energy: implications for the environmental Kuznets curve, Ecological Economics, 25, pp. 195-208.

46. Torras, M., Boyce, J.K. (1998). Income, inequality and pollution: a reassessment of the environmental Kuznets Curve, Ecological Economics, 25, pp. 147-160.

47. UNCTAD, United Nations Conference on Trade and Development. (2014). World Investment Report 2014: Investing in the SDGs: An Action Plan. United Nations, New York and Geneva.

48. Xing, Y., Kolstad, C.D. (2002). Do lax environmental regulations attract foreign direct investment? Environmental and Resource Economics, 21, pp. 1-22.

49. YOIKK, The Coordination Council for the Improvement of Investment Environment. (2013). Foreign Direct Investments in Turkey 2012, General Directorate of Incentive Implementation and Foreign direct investment, Republic of Turkey Ministry of Economy. 


\section{Appendix}
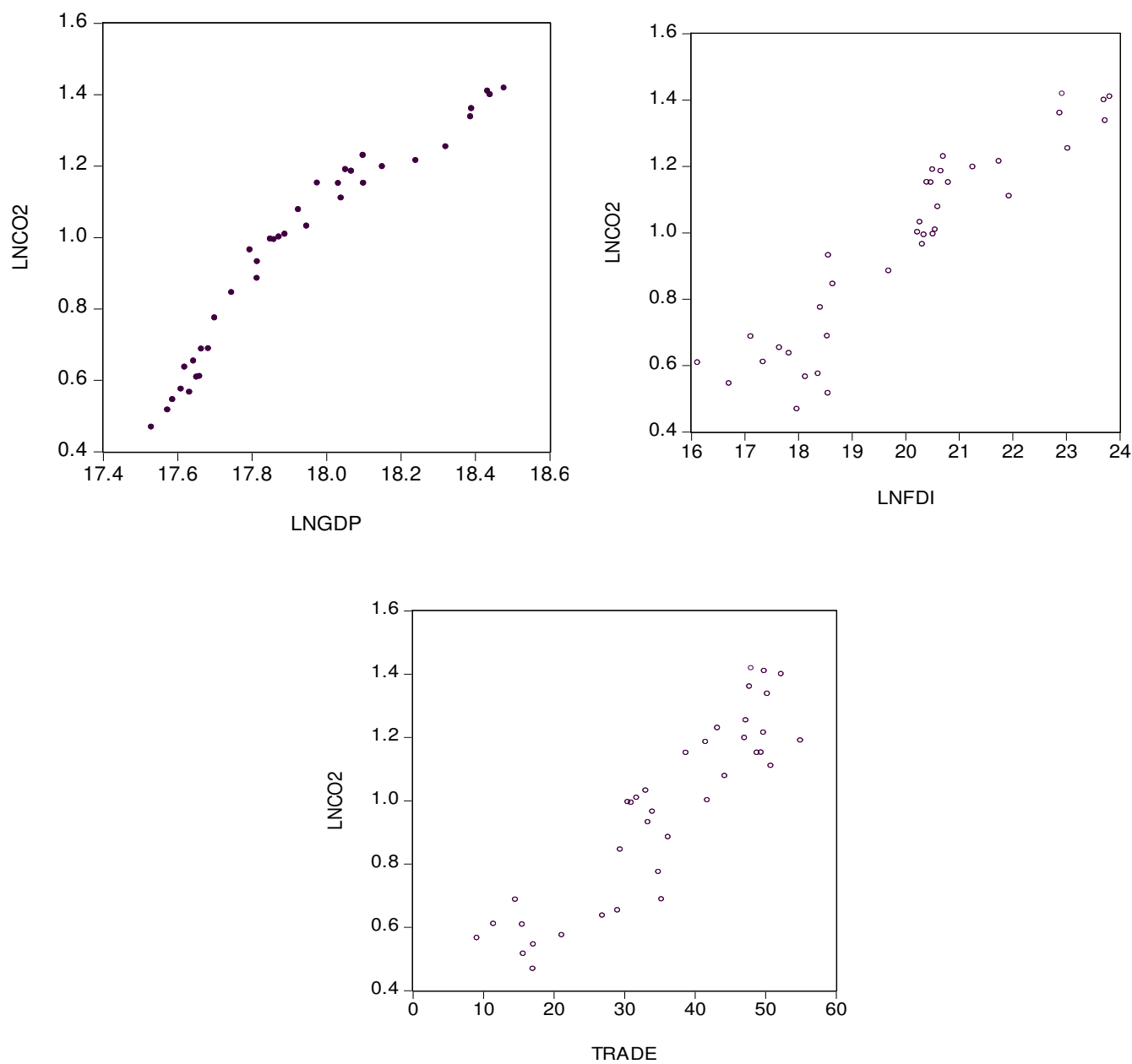

Fig. 1. Scatter plots for $\ln \left(\mathrm{CO}_{2}\right)$ and explanatory variables 